\title{
Proposal of Technical and Commercial Arrangements for Distributed Generation from the Use of Biogas in a Food Industry
}

\author{
A. C. L. Ramos ${ }^{1,2}$, W. P. Calixto ${ }^{1,2}$, A. J. Alves ${ }^{2}$, E. G. Domingues ${ }^{2}$, S. B. de Oliveira ${ }^{2}$, S. T. Coelho ${ }^{3}$. \\ ${ }^{1}$ Program in Electronic Systems and Automation, University of Brasilia, Brazil \\ e-mail: alessandro.clr@celg.com.br; wpcalixto@ieee.org
}
${ }^{2}$ NEXT-nucleus of Studies Experimental and Technological, Electrotechnical Department - Federal Institute of Goias, Brazil e-mail: aja@ifg.edu.br; $\underline{\text { elder.domingues@ifg.edu.br; }} \underline{\text { dr_botelho@yahoo.com.br }}$

${ }^{3}$ The Brazilian Reference Center on Biomass - CENBIO, University of São Paulo - USP, São Paulo, Brazil, e-mail: $\underline{\text { suani@iee.usp.br }}$

\begin{abstract}
The main objective of this work is to perform analyzes of technical and economic viability for distributed generation from burning methane gas produced in a effluent anaerobic bioreactor of a food industry located in the middle west area of Brazil. The study proposes technical and commercial arrangements based on the use of a set consisting of a Otto cycle engine directly coupled to a synchronous generator whose power will be injected directly into the local grid. In case of power outages, the system will not stay islanded and the loads from the Wastewater Treatment System will be supplied in a standalone way. The results show that the proposed system is technically and economically viable. The payback period is less than the remaining useful lifetime of the anaerobic digestion system.
\end{abstract}

\section{Key words}

Biogas, Distributed Generation, Food Industry, Economic Viability.

\section{Introduction}

Distributed Generation (DG) is currently seen as the solution to several problems, as well as the source of several benefits with regards to reliability, power quality and environmental issues. For this reason, the electrical power system of the future tends to be decentralized and have a great concentration of small and medium-sized DG power plants. Many of these source technologies for DG are considered as virtual reservoirs that directly aid studies on reliability and planning.

The Brazilian Electric Energy Agency (ANEEL) [1] is responsible for the regulatory aspects of the electricity sector. She has the power to decide to encourage and to submit research \& development projects in the main areas of social interest, among them, the ones related to wider and better energetic use of nonconventional energy sources, such as the ones derived from Liquid and solid effluents, biogas. Brazil has a large amount of liquid and solid effluents that originate from wastewater treatment plants (WTP), landfills, slaughterhouses, farms and industries [1]. These effluents are not used to generate energy, as most of the resulting biogas is burned in flares. Approximately $98 \%$ of the energy recovery in Brazil is concentrated in the sugarcane ethanol industry, and hence other residues play a small part in the country's energy matrix [1].

For the generation of electricity from biogas, the first economic factor that should be being considered is the use of a low-cost fuel, since biogas is a byproduct of a process of anaerobic digestion. [4].

According to the ANEEL, biomass is considered one of the main alternatives for diversification of energy sources, thereby reducing dependence on fossil fuels.

Important aspects should be considered when biomass is used to produce energy:

i) their rational strategies pertaining to the protection of natural resources;

ii) the potential to promote the replacement of the forms of non-renewable energy;

iii) energy recovery by interested segments and economic viability [2].

According to Couto et. al [3], the biogas production fits perfectly between the measures taken by the World Bank for the sustainable use of renewable natural resources, 
reducing pollution and energy waste. Besides being an alternative energy, biogas, byproduct of the process, is a low-cost fuel [4].

Methane, the main component of biogas [5], [6], [7], is the gas that gives the characteristics of fuel. The energy value of biogas is determined by the concentration of methane an average of $8500 \mathrm{kcal} / \mathrm{m}^{3}$. The highly purified biogas can reach up to $12000 \mathrm{kcal} / \mathrm{m}^{3}$ [8].

The primary equipment commonly used in the use of biogas as a fuel to produce electricity are internal combustion engines, mainly because of the costs of acquisition, operation and maintenance (O\&M) [4]. These engines with spark ignition, known as Otto cycle, are much more used than the microturbines. The internal combustion motors can be manufactured in a range that vary from $10 \mathrm{~kW}$ to $1600 \mathrm{~kW}$ [9].

The process of conversion to the use of biogas, with $60 \%$ $80 \%$ of methane [5], as fuel is easier because most gas engines already use natural gas [12]. For the correct sizing of the motor generator group must the following parameters should be used:

i) the efficiency of the engine generator;

ii) the calorific value of biogas;

iii) use time and generation plant, and;

iv) daily availability of biogas in the unit ( $\mathrm{m}^{3} /$ day).

Due to the country's great potential for generating effluents, and seeking to diversify Brazil's energy matrix, ANEEL published Announcement No. 014/12 for power utilities conduct a strategic research project aimed at encouraging this kind of energy generation. Another incentive came from Normative Resolution No. 482/ANEEL, which established the general conditions for access to distributed micro-generation and mini-generation for electric power distribution systems [13].

The studies and research which are presented in this paper are part of a research \& development project approved under ANEEL's Announcement No. 014/12.

\section{Technical and economic assessment for}

\section{the energy generation by using biogás}

\section{A. Structure and investment in wastewater treatment plant (WTP) for the production and combustion of biogas}

Figure 1 shows a WTP of a food industry, located in a middle west area of Brazil. The WTE was built to treat effluents that are released into the water course. The total investment of treatment system was approximately US\$ $6,800.000 .00$. The biogas produced by the facility is being completely burned in two flares, uninterrupted. The average daily production of biogas in the year 2011 was $4,740.42 \mathrm{~m}^{3} /$ day. A second anaerobic reactor was installed in 2012, increasing the average of biogas production to $10,423.87 \mathrm{~m}^{3} /$ day, with an average concentration of methane of $70 \%$.

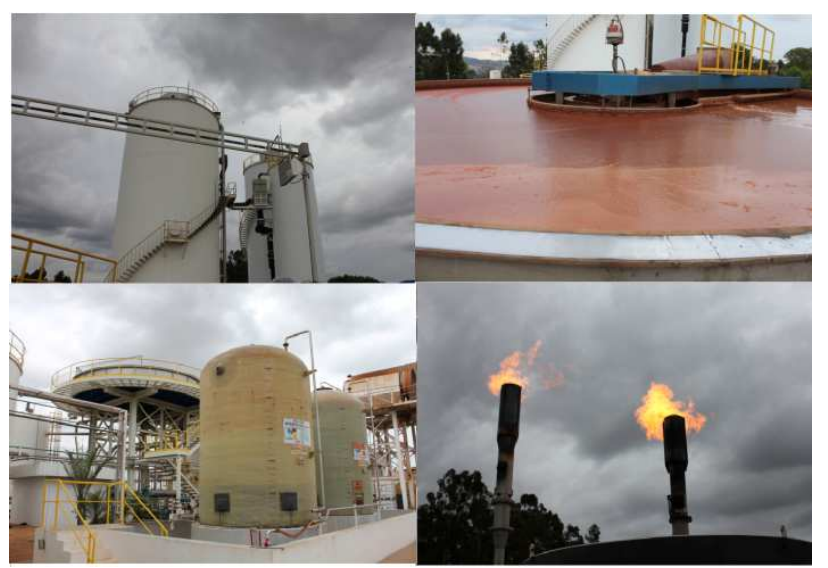

Figure 1- Details of WTP and biogas combustion process.

\section{B. Technical arrangement proposed for the utilization of biogas for generating electricity}

The technical arrangement proposed is showed in figures 2 and 3 . The biogas produced $\left(10,423.87 \mathrm{~m}^{3} /\right.$ day), that is currently burned into two flares, should be filtered and stored in order to produce electricity by using motorgenerator groups of internal combustion. The electricity produced is injected into the local distribution company, according to the Normative Resolution No. 482/ANEEL [13], which establishes the general conditions for access to distributed micro-generation for electric power distribution systems.

The Distributed Generation is injected into the local utility grid or, in the absence of utility power, the loads of WTP, which correspond to approximately $350 \mathrm{~kW}$, would be supplied by the microgenerator, avoiding problems related to the effluent treatment. Figure 4 shows the simplified unifilar diagram of the system. This diagram shows the proposed technical arrangement for the microgeneration, food industry and its WTP.

To avoid islanding of DG, a protection system of the generation plant will be deployed as distribution procedures indicated in [10].

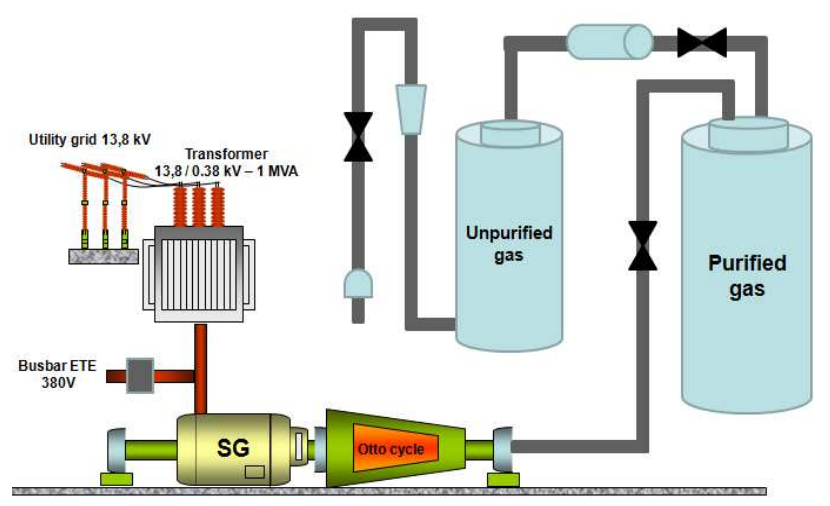

Figure 2 - Illustration of the plant to be installed. 


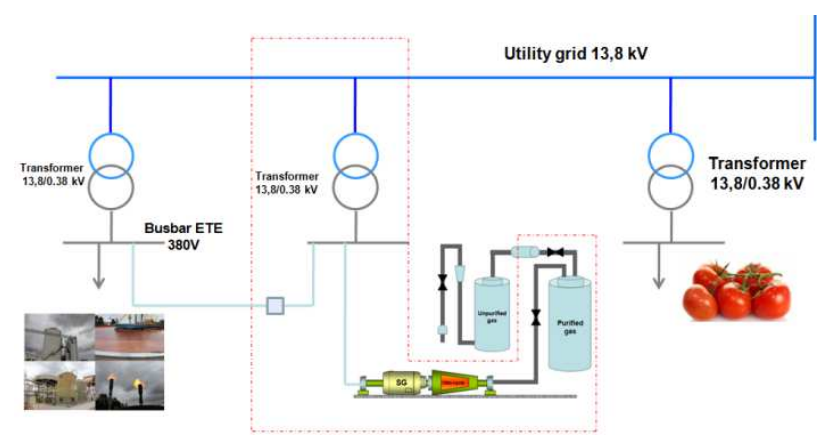

Figure 3 - Proposed Technical Arrangement.

\section{Evaluation of the potential power generation}

The electrical power generated from biogas can be calculated by using the equation 1 [9].

$$
P_{g e}=\frac{Q_{B i o g a ́ s} \cdot L C V_{C H 4} \cdot C_{M} \cdot n_{M o t o r} \cdot n_{G e r a d o r} \cdot F_{C}}{C k w}
$$

Where:

$\boldsymbol{P g} \boldsymbol{e}$ - generated power $(\mathrm{kW}) ;$
$\boldsymbol{Q}_{\boldsymbol{B}}$ - amount of biogas $\left(\mathrm{m}^{3} / \mathrm{h}\right) ;$

$L C V_{\mathrm{CH}_{4}}$ - Lower Calorific Value of Methane

$\left(\mathrm{kcal} / \mathrm{m}^{3}\right)$;

$\boldsymbol{C}_{\boldsymbol{M}}$ - percentage of methane in biogas (\%);

$\boldsymbol{n}_{\boldsymbol{M}}$ - engine efficiency (\%);

$\boldsymbol{n}_{\boldsymbol{G}}$ - generator efficiency $(\%)$;

$\boldsymbol{F}_{\boldsymbol{C}}$ - Correction factor due to uncertainties (\%).

This factor take into account the losses in the pipes, mechanical couplings, the presence of other gases not fully quantified and other factors that lead to losses in the final energy;

$\boldsymbol{C} \boldsymbol{k} \boldsymbol{w}-\mathrm{kcal}$ conversion in $\mathrm{kWh}$.

The values of the above parameters are shown in the Table 1.

Table 1 - Values of the parameters to obtain the power generation potential.

\begin{tabular}{|c|c|c|c|c|c|c|}
\hline $\begin{array}{c}\mathrm{Q}_{\mathrm{B}} \\
\left(\mathrm{m}^{3} / \mathrm{h}\right)\end{array}$ & $\begin{array}{c}P C I \\
\left(\mathrm{kcal} / \mathrm{m}^{3}\right)\end{array}$ & $\begin{array}{c}\mathrm{C}_{\mathrm{M}} \\
(\%)\end{array}$ & $\begin{array}{c}n_{M} \\
(\%)\end{array}$ & $\begin{array}{c}n_{G} \\
(\%)\end{array}$ & $\begin{array}{c}\mathrm{F}_{\mathrm{C}} \\
(\%)\end{array}$ & $\mathrm{Ckw}$ \\
\hline 434.33 & 8500 & 0.70 & 0.34 & 0.95 & 0.90 & 860 \\
\hline
\end{tabular}

From the volume of methane produced in the food industry, the useful electrical power available is equal to $873.54 \mathrm{~kW}$.

\section{Economic Viability}

The estimative of power generated by the biogas produced in the WTP is approximately $830 \mathrm{~kW}$ (average). Taking into account the capacity factor equal to 0.9 , and other expenses with pumping and gas compression, this value reaches approximately $747 \mathrm{~kW}$, that corresponds to 6.7 GWh per year.
The preliminary economic viability was obtained by using the methodology for unit cost analysis, presented in [4].

Table 2 shows the costs involved in the energy conversion system. The present value of the energy conversión system is equal to US\$ 973,956.45. Table 3 shows the biodigester invesment cost, the annualized investment cost and the operating and maintenance costs (O\&M) to produce $3,650.000 \mathrm{~m}^{3} / \mathrm{yr}$ of biogas. The anual biogas expenditure is equal to US\$709,387.35. The cost of capital was considered equal to $7.25 \%$ per year (Celic interest rate).

Table 2 - Costs of energy conversion system.

\begin{tabular}{|c|c|c|}
\hline description & amount & price (US\$) \\
\hline Generator - $850 \mathrm{~kW}$ & 01 & $579,545.00$ \\
\hline $\begin{array}{l}\text { Present value }(\mathrm{PV}) \text { of the } \\
\text { acquisition cost of the } 850 \mathrm{~kW} \\
\text { engine in the } 7^{\text {th }} \text { year }\end{array}$ & 01 & $84,920.40$ \\
\hline Facilities: rails, cables etc. & 01 & $90,909.10$ \\
\hline Engine Room & 01 & $34,690.90$ \\
\hline Bidirectional power meter & 01 & $9,091.00$ \\
\hline $\begin{array}{lcc}\text { Instrument and tool for } \\
\text { assembly and maintenance }\end{array}$ & several & $36,363.65$ \\
\hline $\begin{array}{l}\text { Purification, cleaning and } \\
\text { storage systems }\end{array}$ & 01 & $138,436.40$ \\
\hline $\begin{array}{l}\text { Present value of the total } \\
\text { investment cost }\end{array}$ & \multicolumn{2}{|c|}{$973,956.45$} \\
\hline $\begin{array}{l}\text { Annualized cost of energy } \\
\text { coversion system }\end{array}$ & \multicolumn{2}{|c|}{$113,042.50$} \\
\hline
\end{tabular}

Table 3 - Costs of Biodigester System.

\begin{tabular}{|l|c|}
\hline \multicolumn{1}{|c|}{ description } & values \\
\hline Biodigester (US\$) & $4,545.454 .50$ \\
\hline $\begin{array}{l}\text { Annualized cost biodigester system - } \\
\text { (US\$) }\end{array}$ & $527,569.15$ \\
\hline $\begin{array}{l}\text { Annual operation and maintenance cost } \\
\text { - (US\$) }\end{array}$ & $181,818.20$ \\
\hline Annual cost of biogas - (US\$/m ${ }^{3}$ ) & 0,19 \\
\hline Annual biogas expenditure - (US\$) & $709,387.35$ \\
\hline
\end{tabular}

The preliminary estimative for the economic viability indicated: a simple payback equals to twelve (12) years and six (6) months and the energy cost produced by the plant equals to US\$ $0.13 / \mathrm{kWh}$. The revenue from the electricity sale is equal to US\$ 446,281.70/yr.

This preliminary evaluation considered:

i) all WTP investment that has already been done to produce and burn the biogas and also lagoons cost;

ii) remaining lifetime of the anaerobic digestion plant equals to 14 years;

iii) the operating and maintaining costs of the anaerobic digestion system and energy conversion system were considered equal to $4 \%$ of the total investment in system;

iv) the average price of the electricity generated equal to US\$ 68.20/MWh. This value is considered a modest and may fluctuate 
according to the discounts and or incentives to be given, particularly in rates of system use.

The Payback period is less than the remaining life of the plant (14 years).

The analyzes took into consideration only the gross revenue from the electricity sale. It were not included the revenue from carbon credits and the economy that can be obtained from the use of sludge that could be dry and used as fuel in the biomass boiler.

It is posible to increase the biogas production by using the proper temperature control of the process. Another possibilities to improve the efficiency of the process are:

- Inserting in the WTP plant the process of drying the sludge derived from the anaerobic reaction, that can be used as fuel in boilers or as fertilizer and soil treatment (fertirrigation);

- Biogas treatment to optimize the amount of methane produced and remove the harmful components to equipment, in order to increase the lifetime of the Otto cycle engine;

- Good prospects for the expansion of the effluents production process due to expansion of the food industry;

- Possibility of increasing the value of US $\$ / \mathrm{kWh}$ with the storage of biogas for higher generation at the peak hours.

- Sale of carbon credits;

- Search of tax incentives for the reduction or exemption of tariffs such as the Usage Tariff of the Distribution System, and connection agreement to the Distribution System. Other incentives are shown in [11].

\section{E. Commercial arrangement proposed}

All produced energy will be connected to the local distribution company, in $13,8 \mathrm{kV}$, According to procedures for the distribution of electricity, normative document drawn up by the Brazilian Electric System Operator, which define the procedures and requirements necessary to perform activities of operation planning, transmission management, scheduling and real-time operation of the National Electric System.

The comercialization of the electricity produced will occur through the celebration of bilateral contract between the local energy company and the food industry. In the contract should be established the price, the quantity and period of time. The division of the cash flow should e proportional to the capital invested by each company.
The generation company will receive in return for a proportion of their investment, when the implementation of the plant, revenues from the sale of electrical energy for their own food industry, especially as a consumer, in accordance with current legislation by supply contract duly registered with the chamber of sale of electricity (CCEE).

The food industry will receive in return for the production, the supply of biogas and the provision of services of operation of the plant, reducing the purchase price of the energy consumed in its manufacturing plant, corresponding to the amount of fuel consumed, whose values are reset in the spreadsheet composite cost of the energy produced at the power plant, as long as their supply contracts by the plant and captive consumers free or serviced by the utility.

\section{Conclusion}

Simulations have shown that, for the sale price of the energy of US\$ 68.20/MWh, the payback would be, approximately, twelve years and six months, which is less tan the remaining useful life of the anaerobic digestion system.

The project appears to be extremely viable, taking into account the payback of the project, the potential revenue from the sale of carbon credits, the savings with the possible use of sludge as fuel for biomass boiler, and possible tax incentives to reduce or exemption of the usage tariff and conection agreement to the Distribution Company. The cost of methane is zero due to the fact that the the methane is already being burned.

Whereas various food industries, breweries, slaughterhouses, farms, swine production farms in Brazil are burning biogas due to environmental issues, and considering federal incentives for the use of biogas to generate energy, it can be said that in a short period of time several works and such exploitations are emerging, mainly due to the great advantages of economic and technical feasibility presented.

\section{Acknowledgement}

For the realization of this work we thank CELG Generation and Transmission SA - CELG GT by prospective vision of the project and other cooperative enterprises, especially to researchers at the Federal Institute of Goias (IFG) for believing and accepting the invitation CELG GT for the completion of major project research, and CELG Distribution SA by the partnership and contribution. The CELG Generation and Transmission SA in conjunction with other companies cooperated, was the only transmitter of electricity in the country who 
submitted to ANEEL project that treats wastewater from the food industry.

\section{References}

[1] ANEEL - National Agency of Electric Energy (2008). BIOMASS. Atlas Energy in Brazil. Chapter 4. 3rd Edition. Brasilia, 2008. (In Portuguese)

[2] COUTO, L. C., FARINHA, L., BARCELlOS, D. C. (2004) pathways of energy valorisation from biomass. Biomass and Energy. Viçosa, v.1, n.1, p.71 - 92. (In Portuguese)

[3] AVELLAR, L. H. N.; COELHO, S. T.; ALVES, J. W. (2001) Electricity Generation with Biogas: A Reality. Journal Biotechnology, Science and Development (online), São Paulo, v. 29. (In Portuguese)

[4] PECORA, V. (2006). Implementation of a demonstration unit of electricity generation from biogas sewage treatment residential USP - case study. São Paulo. Dissertation, University of São Paulo - USP. (In Portuguese)

[5] Schomaker, A. et al., "Anaerobic Digestion of AgroIndustrial Wastes: Information Networks Technical Summary on Gas Treatment”, AD_NETT Project FAIR-CT96-2083 (DG12SSMI), August 2000.

[6] Clampdown on emissions from landfill gas flares. UK Policy, ENDS Report 290.

[7] Gas Utilization from Sewage Waste Allan K. Chambers and Ian Potter Carbon and Energy Management Alberta Research Council Edmonton, Alberta, T6N 1E4, Canada.

[8] COPEL - Energy Company paranaense. (2011). Sources of Energy - Biomass. (In Portuguese)

[9] PRATI, L. Generation electricity from biogas generated Biodigestores. Monograph. Graduate Course of Electrical Engineering, Federal University of Paraná. Curitiba, 2010. (In Portuguese)

[10] ANEEL - National Agency of Electric Energy (2008). PRODIST. Procedures for Electric Power Distribution. Submodule 3. In 2012. (In Portuguese)

[11] J. P. Painuly. Barriers to renewable energy penetration; a framework for analysis. Diffusion of renewable energy technologies-barriers and stakeholders' perspectives, Renewable Energy, 2004 - Elsevier.

[12] GE-Energy. (2011). Jenbacher biogas engine. Catálogos. CARTEPILLAR. Gás generator sets. Catalogs informative. Available at www.cat.com Acesso em 23 Nov 2011.

[13] ANEEL - National Agency of Electric Energy (2012). Normative Resolution No. 482. Establishes the general conditions for access minigeneration and microgeneration distributed systems for power distribution, the compensation system for electricity, and other measures. (In Portuguese) 